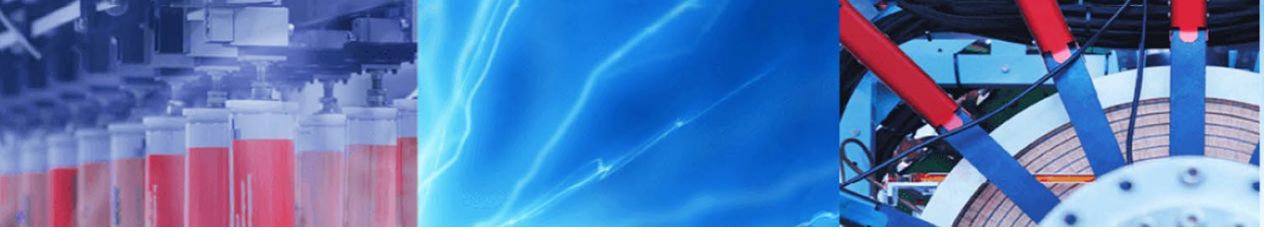

Research Article

\title{
Feeding strategies for small-scale rearing black soldier fly larvae (Hermetia illucens) as organic waste recycler
}

\author{
Daniel Dzepe ${ }^{1,2,3} \cdot$ Paulin Nana $^{4} \cdot$ Hervé Mube Kuietche $^{3,5} \cdot$ Janaina Mitsue Kimpara ${ }^{6}$. Ornela Magatsing ${ }^{1}$. \\ Timoléon Tchuinkam ${ }^{1} \cdot$ Rousseau Djouaka ${ }^{2,3}$
}

Received: 3 September 2020 / Accepted: 21 December 2020 / Published online: 2 February 2021

(C) The Author(s) 2021 OPEN

\begin{abstract}
Processing organic waste using black soldier fly (BSF)-based technology offers a promising alternative for sustainable organic waste management and urban sanitation. This study was conducted to assess the influence of feeding strategies on the efficacy of BSF larvae to recycle organic wastes into value products. Fruit waste and chicken manure were used as organic waste samples while commercial chicken feed was used as a control, and were processed for 15 days in circular plastic containers $(\varnothing 30 \times 12 \mathrm{~cm})$ with 50; 100; 150; and $200 \mathrm{mg} /$ larva/day continuous and batch feeding diets, using 500 four-day-old larvae per diet, repeated four times. Larval survival rates were not significantly affected by the feeding strategies. However, average larval biomass of $83.69 \pm 13.04 \mathrm{~g}$ and $82.46 \pm 08.52 \mathrm{~g}$ was achieved for the continuous and batch feeding strategies, respectively, under favorable conditions. Larval feed reduction rates ranged from $24.65 \pm 03.48 \%$ to $72.78 \pm 01.48 \%$ and $24.52 \pm 0.27 \%$ to $72.25 \pm 12.13 \%$ with continuous and batch feeding strategies, respectively, and were significantly affected by the different daily diets. On the other hand, the bioconversion rates ranged from $13.34 \pm 0.26 \%$ to $50.82 \pm 02.27 \%$, and the highest values were observed with the continuous feeding diets. This study confirms the efficacy of BSF larvae to thrive in different organic substrates and shows that the continuous feeding strategy can be better and enhance a sustainable small-scale organic waste management.
\end{abstract}

Keywords Animal feed · Bioconversion · Larval biomass · Waste management

\section{Introduction}

In low- and middle-income countries, indiscriminate disposal, poor-quality treatment and uncontrolled landfilling of organic waste contribute to negative environmental and public health outcomes $[1,2]$. Up to $85 \%$ of household wastes are biodegradable while about half of the wastes are from food. Globally, about 1.3 billion tonnes of food are wasted each year, which equates to an annual economic loss of about $\$ 1$ billion [3]. Poor organic waste management practices also waste energy and the nutrients that could be used to meet the increasing global resource demand $[4,5]$. Therefore, there is a pressing need for developing multiple potential food waste valorization technologies to reduce as well as mitigate the adverse effects of food waste. Processing of organic waste using fly larvae is a relatively new concept which is currently attracting interest [6-9].

As detritivores, the diversity of holomtabolous insects includes black soldier fly (BSF) larvae specializing in their

Daniel Dzepe, danieldzepe@gmail.com | 1 Vector Borne Diseases Laboratory of the Applied Biology and Ecology Research Unit, Faculty of Sciences, University of Dschang, P.O. Box 067, Dschang, Cameroon. ${ }^{2}$ International Institute of Tropical Agriculture, P.O. Box 0932, Cotonou, Benin. ${ }^{3}$ Agri-Business Vocational Training Center, Dschang, Cameroon. ${ }^{4}$ School of Wood, Water and Natural Resources, Faculty of Agronomy and Agricultural Sciences, University of Dschang, Ebolowa Campus, P.O. Box 786, Ebolowa, Cameroon. ${ }^{5}$ Research Unit in Animal Nutrition and Production, Faculty of Agronomy and Agricultural Science, University of Dschang, P.O. Box 222, Dschang, Cameroon. ${ }^{6}$ Brazilian Agricultural Research Corporation, Embrapa Meio-Norte, Parnaíba, PI, Brazil. 
ability to thrive on different organic substrates as food sources [10-12]. These substrates are most often food waste from agriculture and food processing industries. BSF larva is one of the detritivores dipterans studied to convert organic waste into biofertilizers and larval biomass, which can be used, respectively, to improve poor soils and as sources of proteins and dietary fats for animal feed $[13,14]$. BSF is a complete metamorphosis insect which, during its larval stage, feeds voraciously on a varied range of organic waste and efficiently converts nitrogen compounds and carbohydrates into larval biomass. Their nutritional values have been evaluated and can be compared with those of animal protein sources usually used in animal feed $[15,16]$. In the literature, this is recognized as insects-based technology and represents an economically viable method for recycling large quantities of food waste into valuable products.

Sustainable organic waste management is classified among the priorities of countries wishing to ensure the best living conditions for their citizens [17]. In Cameroon, like in most African countries, composting is one of the most advanced techniques for recycling and recovering food waste [18-20]. Composting is the decomposition of organic matter and their transformation into humus by the action of a great number of microorganisms in a hot, humid and ventilated environment [21,22]. This process can take several months and produce compost as the only valuable product. In contrast, organic waste management using BSF larvae does not require specific microorganisms and only takes about two weeks to produce organic fertilizers which can be used in production of crops, and larval biomass which can be used as a source of proteins for livestock or as a biofuel precursor for diesel engines [15, 23, 24]. It should also be noted that the treatment of organic waste based on BSF larvae offers a promising alternative for environmental safety. Because by converting nitrogen compounds and carbohydrates from organic waste, it contributes to the reduction of greenhouse gas emissions and therefore leading to global warming [25-27].

Various studies have investigated into the effects of different organic waste streams on laboratory-reared BSF [28-30], as well as the influence of animal manure or food waste on the development and survival of BSF larvae using experimental prepared diets $[8,28]$. Other studies have investigated the potential of BSF larvae to recycle these organic wastes into useful products [31-33]. However, most of these studies focus on the waste stream-based diets and lack information on the effects of feeding strategy. For example, what will happen if a given amount of organic waste is defined and fed to the BSF larvae once at the start for the entire development period? Would providing BSF larvae with small amounts of waste every day improve their recycling and conversion efficiencies? To the best of our knowledge, no study so far has investigated the combined effect of different organic wastes stream-based diets and feeding strategy on the recycling and converting activities of BSF larvae in a given facility. Therefore, this study aimed to investigate the influence of feeding strategy on the efficacy of BSF larvae to thrive in different organic wastes stream-based diets with an overview of their recycling and converting activities. Information from this study is important for improving small-scale organic waste management using BSF-based technology, as well as the production of environmentally sustainable livestock feed for smallholder farmers.

\section{Materials and method}

\subsection{Black soldier fly colony}

This study was carried out in a greenhouse at the AgriBusiness vocational training Center ( $A B C)$, Dschang, Cameroon. BSF colony was established in 2017 from larvae of wild-trapped Hermetia illucens populations breed since 2016 at the International Institute of Tropical Agriculture (IITA), Yaoundé, Cameroon. BSF egg clusters from the pre-established colony were incubated according to the method described by Dzepe et al. [9]. After hatching, a total number of 48000 four-day-old larvae were collected and divided into two equal groups used to test two feeding strategies (continuous and batch feeding strategies). The continuous feeding strategy consisted of a treatment in which the organic substrate was continuously supplied in different diets to the larvae every two days, while in the batch feeding strategy, the different daily diets were calculated for 15 days and supplied to the larvae once at the start of the experiment.

\subsection{Organic waste sample}

Fruit waste and chicken manure were used as organic waste samples, while chicken feed was used as a control substrate. Fruit waste was constituted mainly with papaya, pineapple and orange and was collected in the bins of fruit sellers in the Dschang market, while fresh chicken manure was collected from a broiler farm at the University of Dschang. Chicken feed was purchased from a commercial animal feed company in Cameroon, and its composition is: $22 \%$ crude protein, $6 \%$ fat, $3.5 \%$ crude fiber and $5 \%$ crude ash. The collected fruit waste and fresh chicken manure were stored for two days to reduce the water content, and a $50 \mathrm{~g}$ sample was taken from each and oven-dried for $24 \mathrm{~h}$ at $100^{\circ} \mathrm{C}$ to determine their humidity rate using relation (Eq. 1). 
Humidity rate $(\%)=[1-($ dried weight $/ 50)] \times 100$.

The dry chicken feed on the other hand was moistened at $60 \%$ with fresh water before use. The water contents of the first two substrates were $90.42 \pm 1.05 \%$ and $69.87 \pm 2.85 \%$, respectively, for fruit waste and chicken manure. These values are within the suitable range for BSF organic waste processing as recommended by Cammack et al. [34] and Dortmans et al. [35].

\subsection{Experimental design}

\subsubsection{Continuous feeding treatment}

The experiments were carried out in circular plastic containers $(\varnothing 30 \times 12 \mathrm{~cm})$, covered with mosquito nets to prevent BSF larvae predators. Four seeded containers of 500 four-day-old larvae each were used for each organic substrate sample. The different containers were supplied every two days with 50; 100; 150; and $200 \mathrm{~g}$ of their respective substrates, in order to achieve the daily diets of 50; 100; 150; and $200 \mathrm{mg}$ per larva, respectively. Each treatment was repeated four times and the duration of the experiment was determined according to the required time of BSF larvae to reach maturity which was approximately 15 days.

\subsubsection{Batch feeding treatment}

This treatment was carried out under the same conditions as with continuous feeding treatment while the only difference was that for each substrate, the diets were calculated for 15 days according to the different daily diets of $50 ; 100 ; 150$; and $200 \mathrm{mg} / \mathrm{larva}$ and supplied to the containers in batches once at the start of the experiment. The different containers each seeded with 500 four-day-old larvae received, respectively, 375; 750; 1125 ; and $1500 \mathrm{~g}$ of their respective substrate for the duration of the treatment. Table 1 summarizes the different treatments performed in this study.

\subsection{Organic waste recycling parameters}

For each treatment, the larvae were harvested on the 15th day in the containers, counted and weighed using an electronic weighing balance readable to $0.01 \mathrm{~g}$, after washing with fresh water. Residual substrates were also collected from the containers and weighed using an electronic scale of precision $\pm 0.1 \mathrm{~g}$, and subsequently, a sample of $50 \mathrm{~g}$ of each residual substrate was taken into an oven for $24 \mathrm{~h}$ at $100^{\circ} \mathrm{C}$ to determine its dry weight. To take into account both the sustainable organic waste recycling and the larval biomass production, the efficacy of BSF larvae to thrive in the different organic waste samples according to the continuous and batch feeding treatments was assessed using parameters such as larval survival rate (1); larval wet weight (2); waste reduction rate (3); waste reduction index (4); and larval bioconversion rate (5). These parameters were calculated using the following formulas:

1. The larval survival rate (SR) was calculated for each treatment as follows (Eq. 2).

$$
\mathrm{SR}(\%)=\frac{\text { Number of larvae harvested }}{\text { Number of four days old larvae added }} \times 100
$$

2. The larval wet weight was considered as the final weight of the larvae harvested in each treatment at the end of the experiment and was measured using an electronic weighing balance readable to $0.01 \mathrm{~g}$

3. The waste reduction rate (WR) was estimated for each treatment based on the dry weight of the substrates using the formula (Eq. 3).

WR $(\%)=[1-($ Substrate residue/Substrate added $)] \times 100$

The substrate residue is the substrate obtained after larval conversion.

4. The waste reduction index (WRI) takes into account not only the overall material reduction but also the time require by the larvae to reduce this amount of waste and was estimated as follows (Eq. 4).

$$
\mathrm{WRI}=(\mathrm{WR} / t) \times 100
$$

\begin{tabular}{|c|c|c|c|c|c|c|c|c|}
\hline \multirow[b]{2}{*}{ Diets (mg/larva/jour) } & \multirow[b]{2}{*}{50} & \multicolumn{4}{|c|}{ Continuous feeding } & \multicolumn{3}{|c|}{ Batch feeding } \\
\hline & & 100 & 150 & 200 & 50 & 100 & 150 & 200 \\
\hline Nomber of larvae (n) & 500 & 500 & 500 & 500 & 500 & 500 & 500 & 500 \\
\hline Quantity of substrate (g) & 375 & 750 & 1125 & 1500 & 375 & 750 & 1125 & 1500 \\
\hline \multicolumn{2}{|l|}{ Feeding occasions (n) } & \multicolumn{4}{|c|}{ Every two days } & \multicolumn{3}{|c|}{$\begin{array}{l}\text { Once at the } \\
\text { start }\end{array}$} \\
\hline Treatment replicates (n) & 4 & 4 & 4 & 4 & 4 & 4 & 4 & 4 \\
\hline
\end{tabular}

Table 1 Description of the different treatments performed during the study 
WR represents the total amount of organic material reduces during the time $t$. High WRI values indicate good reduction efficiency.

5. The bioconversion rate (BR) was estimated for each treatment using the formula (Eq. 5).

$$
\mathrm{BR}(\%)=\frac{\text { Wet weight of havested larvae }}{\text { initial dry weight of substrate added }} \times 100
$$

Like the waste reduction index, a high bioconversion rate indicates good bioconversion efficiency.

\subsection{Statistical analysis}

The collected data were analyzed statistically using $R$ 3.5.0 software. One-way analysis of variance followed by the Tukey post hoc test was performed to determine the differences between the treatments according to the substrates, while the Student $t$ test was performed to compare the variation of the different parameters between the continuous and batch feeding strategies. A $p$ value $<0.05$ was considered to indicate a significant difference between the values compared.

\section{Results}

\subsection{Larval survival rate}

The survival rates recorded during continuous and batch feeding treatments were not significantly affected by the daily diet $(p>0.05)$, except those of the larvae subjected to continuous feeding diets with fruit waste which recorded significant variations $(p<0.05)$. Furthermore, for each daily diet these survival rates varied significantly depending on the type of substrate $(p<0.05)$, and the larvae subjected to chicken manure recorded the highest values during both continuous and batch feeding treatments (Fig. 1). The comparison of both treatments does not show significant difference $(p>0.05)$.

\subsection{Larval biomass}

The BSF larval biomass from different treatments varied significantly according to the substrate and daily diet $(p<0.05)$. The values from continuous feeding treatments were directly proportional to the different daily diets with chicken manure and fruit waste. Those of the larvae from chicken feed do not show significant variation at 100, 150 and $200 \mathrm{mg} / \mathrm{larva}$ daily diets $(p>0.05)$. The same trends were observed with batch feeding treatments. However, regardless of the daily diet, the highest larval biomass was
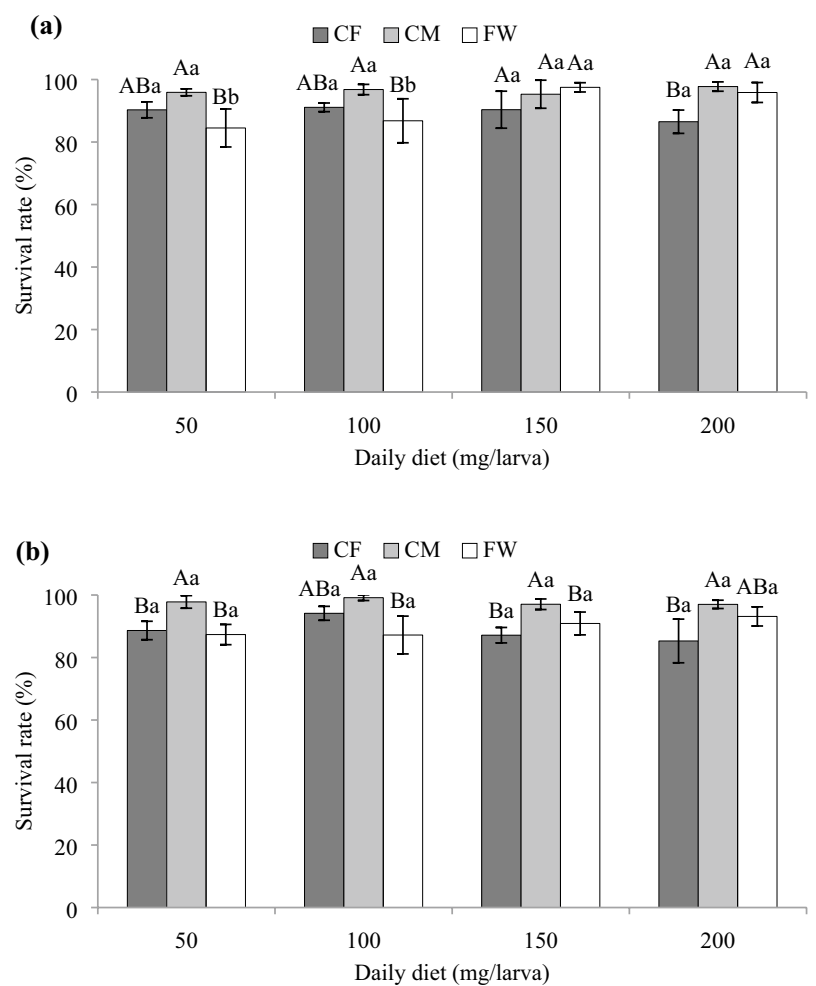

Fig. 1 Survival rates of BSF larvae subjected to different substrates using continuous (a) and batch (b) feeding diets. Means ( \pm SE) followed by different upper-case letters are significantly different among substrates $(p<0.05)$. Means followed by different lowercase letter are significantly different among diets $(p<0.05)$. CF, chicken feed; CM, chicken manure; FW, fruit waste

recorded with chicken feed, followed by chicken manure and fruit waste (Fig. 2). When the two feeding strategies were compared, the larval biomasses from continuous feeding treatments were relatively higher than those from batch feeding treatments.

\subsection{Waste reduction rate}

The reduction rate of different substrates subjected to BSF larvae using continuous and batch feeding strategies was all significantly affected by the daily diets $(p<0.05)$. The values recorded ranged from $24.65 \pm 3.48 \%$ to $72.78 \pm 1.48 \%$ and from $24.52 \pm 0.27 \%$ to $82.45 \pm 2.55 \%$, respectively, with continuous and batch feeding diets, regardless of the substrate. Fruit wastes recorded the highest values, followed by the chicken feed and chicken manure (Fig. 3). The reduction rate of the chicken feed did not show significant variation according to the daily diet $(p>0.05)$. However, when the two feeding strategies are compared, the reduction rates of substrates subjected to batch feeding diets were significantly higher than those 

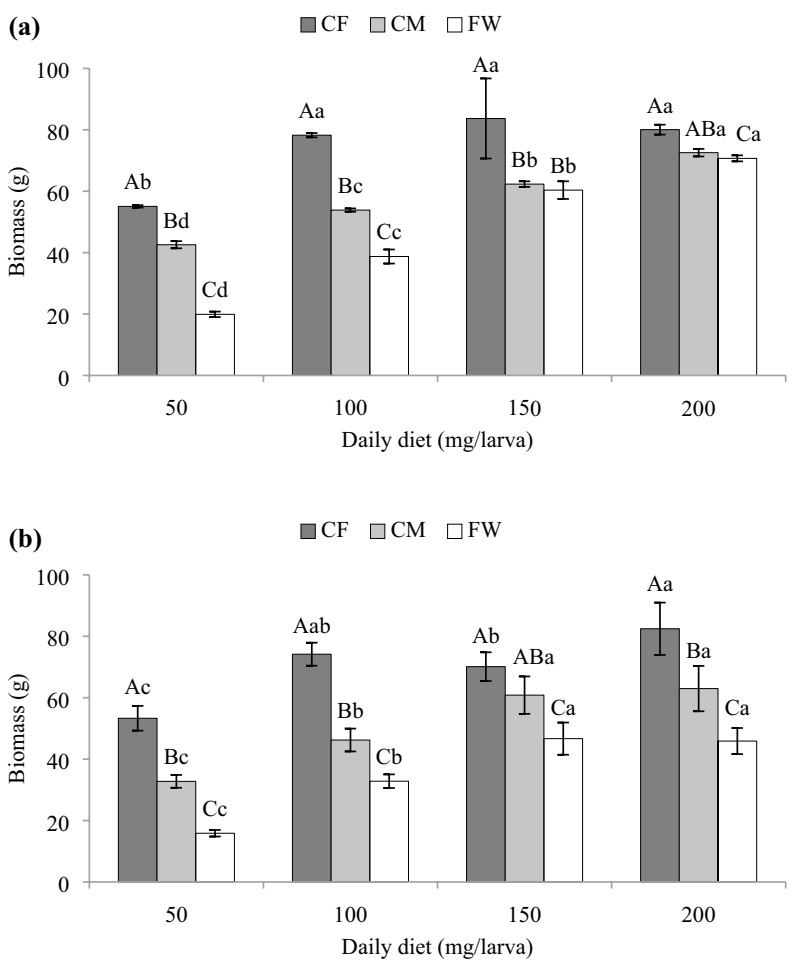

Fig. 2 Biomass of BSF larvae subjected to different substrates using continuous (a) and batch (b) feeding diets. Means ( \pm SE) followed by different upper-case letters are significantly different among substrates $(p<0.05)$. Means followed by different lower-case letter are significantly different among diets $(p<0.05)$. CF, chicken feed; CM, chicken manure; FW, fruit waste

from continuous feeding diets $(p<0.05)$. The same trends were observed with the reduction indices (Table 2 ).

\subsection{Bioconversion rate}

Figure 4 shows the bioconversion rates of BSF larvae obtained in this study. They were significantly affected by the type of substrate, regardless of the feeding strategy and fruit waste recorded the highest values $(p<0.05)$. The daily diets also influenced the conversion of the different substrates with the exception of fruit waste which did not show any significant variation with the diets 50,100 and $150 \mathrm{mg} / \mathrm{larva} /$ day $(p>0.05)$. When the two feeding strategies are compared, the bioconversion rates recorded with continuous feeding diets were relatively higher, although no significant difference was observed $(p>0.05)$.

\section{Discussion}

Black Soldier Fly offers a promising solution to improve the collection and recycling of organic waste, which is actually responsible for many unsanitary problems
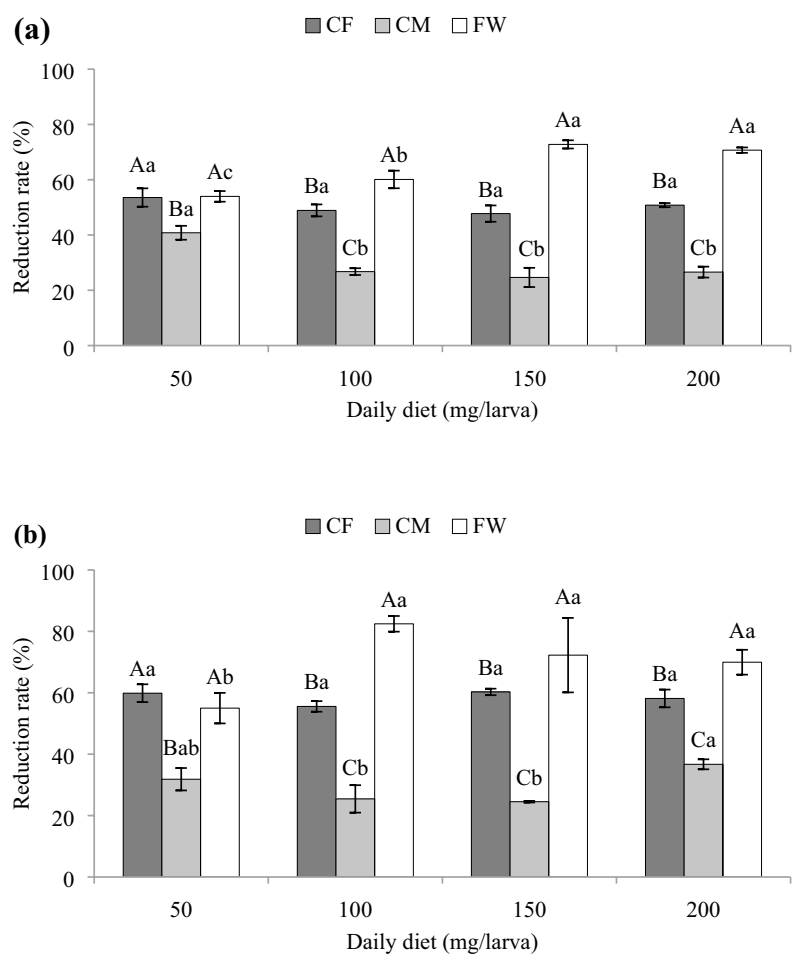

Fig. 3 Reduction rates of organic substrates subjected to BSF larvae using continuous (a) and batch (b) feeding diets. Means $( \pm S E)$ followed by different upper-case letters are significantly different among substrates $(p<0.05)$. Means followed by different lowercase letter are significantly different among diets $(p<0.05)$. CF, chicken feed; CM, chicken manure; FW, fruit waste

encountered in urban areas. During their larval stage, the BSF feeds voraciously on various types of organic waste and converts carbohydrates and nitrogen compounds into secondary protein products $[32,36,37]$. In the present study, the larval survival rates of the BSF were not significantly influenced, both during continuous and batch feeding strategies, except for those of larvae fed on continuous diets with fruit waste. These different survival rates were, however, higher compared to those obtained by Nguyen et al. [38] for BSF larvae in household waste $(47 \%)$, fruit and vegetable waste (77\%). Some authors attribute the low survival rates to the intraspecific competition between individuals for the feed source [39-41] and to the type of substrate [42]. However, Devon [43] obtained low survival rates at the optimal daily diet of $100 \mathrm{mg} / \mathrm{larva}$ as recommended by Diener et al. [36] compared to the $125 \mathrm{mg} / \mathrm{larva}$ /day diet. This could suggest that, in a production system, the daily diet should be adjusted according to the evolution of the larval biomass. It is very important to know at what stage of larval development these mortalities most often occur, in order to determine for how long the larvae must be fed with a specific diet in a given treatment. 
Table 2 Reduction indices of substrates subjected to BSF larvae using continuous and batch feeding diets

\begin{tabular}{lclll}
\hline & $\begin{array}{l}\text { Daily diet }(\mathrm{mg} / \\
\text { larva) }\end{array}$ & CF & CM & FW \\
\hline Continuous feeding & 50 & $3.57 \pm 0.22^{\mathrm{Aa}}$ & $2.72 \pm 0.16^{\mathrm{Ba}}$ & $3.59 \pm 0.12^{\mathrm{Ac}}$ \\
& 100 & $3.26 \pm 0.14^{\mathrm{Bab}}$ & $1.78 \pm 0.08^{\mathrm{Cb}}$ & $4.01 \pm 0.21^{\mathrm{Ab}}$ \\
& 150 & $3.18 \pm 0.19^{\mathrm{Bb}}$ & $1.64 \pm 0.23^{\mathrm{Cb}}$ & $4.85 \pm 0.09^{\mathrm{Aa}}$ \\
Batch feeding & 200 & $3.38 \pm 0.05^{\mathrm{Bab}}$ & $1.77 \pm 0.13^{\mathrm{Cb}}$ & $4.71 \pm 0.06^{\mathrm{Aa}}$ \\
& 50 & $3.99 \pm 0.19^{\mathrm{Aa}}$ & $2.12 \pm 0.24^{\mathrm{Bab}}$ & $3.66 \pm 0.33^{\mathrm{Ab}}$ \\
& 100 & $3.70 \pm 0.11^{\mathrm{Ba}}$ & $1.69 \pm 0.29^{\mathrm{Cb}}$ & $5.49 \pm 0.17^{\mathrm{Aa}}$ \\
& 150 & $4.01 \pm 0.07^{\mathrm{Ba}}$ & $1.63 \pm 0.01^{\mathrm{Cb}}$ & $4.81 \pm 0.80^{\mathrm{Aa}}$ \\
& 200 & $3.87 \pm 0.19^{\mathrm{Ba}}$ & $2.44 \pm 0.10^{\mathrm{Ca}}$ & $4.66 \pm 0.27^{\mathrm{Aa}}$ \\
\hline
\end{tabular}

Means $( \pm S E)$ followed by different upper-case letters are significantly different among substrates $(p<0.05)$. Means followed by different lower-case letter are significantly different among diets $(p<0.05)$. CF Chicken feed; CM Chicken manure; FW Fruit waste
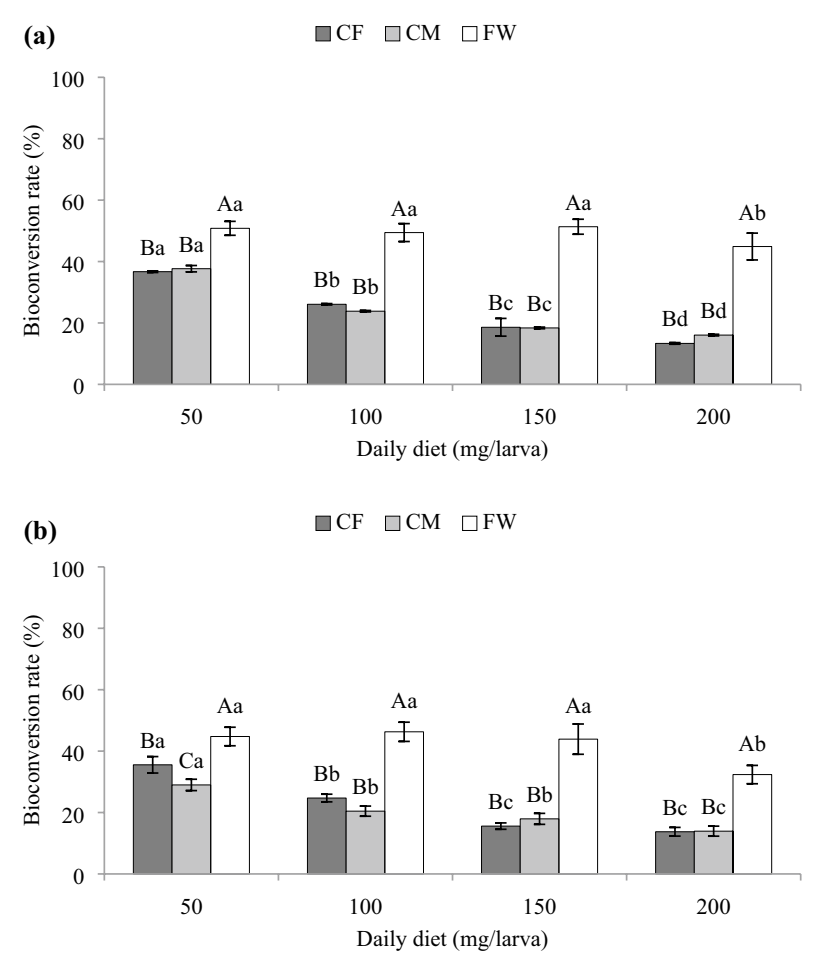

Fig. 4 Conversion rates of organic substrates subjected to BSF larvae using continuous (a) and batch (b) feeding diets. Means ( \pm SE) followed by different upper-case letters are significantly different among substrates $(p<0.05)$. Means followed by different lowercase letter are significantly different among diets $(p<0.05) . C F$, chicken feed; CM, chicken manure; FW, fruit waste

The larvae fed in continuous feeding diets tended to develop fast into large pre-pupae compared to those subjected to the batch feeding diets. Similar results were observed by Nana et al. [32], who argued that BSF larvae have preference for fresh diet as compared with rotten diet. Other authors also demonstrate that most organic wastes lose their nutritional value over time due to the action of microorganisms $[31,44]$. This could explain the difference observed between the larval biomass from continuous and batch feeding diets. These larval biomasses were, however, directly proportional to the daily diet in both treatments, regardless of the different substrates used. These results confirm once again the importance of a balanced diet for small-scale rearing of BSF larvae.

Regardless of the different treatments, larval feed reduction rates were higher with fruit waste compared to chicken manure and chicken feed. The same observations were made by Nguyen et al. [33], who reported that reduction rates of fruits and vegetables by BSF larvae are higher compared to the standard chicken feed. These results could be explained by the texture of fruits wastes, which are generally full of water and easy to degrade. However, for all substrates the values were close to those obtained by various authors in the literature. For example, Cheng et al. [45], respectively, obtain $43 \%$ and $67 \%$ of the reduction rates of dry mass with fruits and vegetables, while Joly [46] obtains $65 \%$ with kitchen waste, and Diener et al. [47] obtain $46 \%$ to $76 \%$ with municipal organic waste. Chicken manure recorded the lowest reduction rates in this study. This could be due to its low energy content as it is a waste product of chicken digestion. Nguyen et al. [33] reported that the energy content of a substrate can affect its reduction efficiency by BSF larvae. Although there were no significant differences, the reduction rates obtained with the larvae subjected to the batch feeding diets were relatively higher as compared to those of the larvae subjected to the continuous feeding diets. This could be due to the action of microorganisms which compete with the larvae for old substrate. This type of substrate is generally characterized by the release of foul smells due to the microorganism's action. Gold et al. [48] have summarized all the degradation processes that occur in organic waste outside the larval organism in a given area. In the batch feeding strategy, the reduction rates of larvae subjected to the control diets (chicken feed) did not show significant variation. This contrast the results achieved by Diener et al. [47] 
that $100 \mathrm{mg}$ of the feed per larva per day is the best diet for organic waste reduction using BSF larvae.

The bioconversion rates recorded in this study were inversely proportional to the daily diets regardless of the different substrates, both continuous and batch feeding treatments. Fruit waste recorded the highest values compared to chicken manure and chicken feed. These results are similar to those obtained by Devon [43] who reports a significantly higher bioconversion rate and feed conversion ratio by the BSF larvae with a daily diet of $125 \mathrm{mg}$ per larva. However, for chicken manure and chicken feed, the values obtained were substantially close to the values in the literature. Nyakeri et al. [31] obtained a bioconversion rate of $22.3 \%$ with human manure at $100 \mathrm{mg} / \mathrm{larva} /$ day diet, while Joly [46] obtained $20.73 \%$ with kitchen waste at $100 \mathrm{mg} /$ larva/day. It is important to note that these values were calculated based on the dry weight of the different substrates. The bioconversion rates calculated based on the wet weights are much lesser than the values obtained in this study, due to the influence of the water content of the substrates $[32,47]$.

\section{Conclusions}

This study provides a context for understanding the efficacy of BSF larvae to recycle organic wastes according to different feeding strategies, with an overview on the larval biomass production which can be used as animal feed in livestock sector. The results showed that BSF larvae are more able to thrive in fresh substrates compared to old substrates and that the best recycling or conversion efficiency is obtained with low continuous daily diets. Regardless of the different treatments, the feed reduction rate varied between 24.52 and $72.78 \%$ and the bioconversion rate varied between 13.34 and $51.34 \%$. This means that with BSF-based technology, a $100 \mathrm{~kg}$ of organic waste can be reduced to between 70.54 and $20.72 \mathrm{~kg}$ and also generate between 10.34 and $50.13 \mathrm{~kg}$ of biomass in just 15 days.

Acknowledgements This research was supported by the AgroEcoHealth Platform of IITA, Under the insects for food and feed project, jointly coordinated by the University of Liverpool UK and IITACC6025/Rousseau DJOUAKA. IITA-Benin, West Africa.

\section{Compliance with ethical standards}

Conflict of interest The authors declare that they have no competing interests.

Open Access This article is licensed under a Creative Commons Attribution 4.0 International License, which permits use, sharing, adaptation, distribution and reproduction in any medium or format, as long as you give appropriate credit to the original author(s) and the source, provide a link to the Creative Commons licence, and indicate if changes were made. The images or other third party material in this article are included in the article's Creative Commons licence, unless indicated otherwise in a credit line to the material. If material is not included in the article's Creative Commons licence and your intended use is not permitted by statutory regulation or exceeds the permitted use, you will need to obtain permission directly from the copyright holder. To view a copy of this licence, visit http://creativecommons .org/licenses/by/4.0/.

\section{References}

1. Hoornweg D, Bhada-Tata P (2012) What a waste. A global review of solid waste management, Urban Development Series Knowledge Papers Washington DC USA

2. Komakech AJ, Banadda NE, Kinobe JR, Kasisira L, Sundberg C, Gebresenbet G, Vinnerås B (2014) Characterization of municipal waste in Kampala Uganda. J Air Waste Manage Assoc 64:340-348

3. FAO (2014) Food and Agricultural Organization of the United Nations. Food Wastage Footprint Full-cost Accounting, Rome

4. Alexander P, Brown C, Arneth A, Finnigan J, Moran D, Rounsevell MDA (2017) Losses, inefficiencies and waste in the global food system. Agric Syst 153:190-200

5. Diener S, Semiyaga S, Niwagaba CB, Muspratt AM, Gning JB, Mbéguéré $M$ et al (2014) A value proposition: resource recovery from faecal sludge - can it be the driver for improved sanitation? Resour Conserv Recycl 88:32-38

6. Makkar H, Tran G, Heuzé V, Ankers P (2014) State-of-the-art on use of insects as animal feed. Anim Feed Sci Technol 197:1-33

7. De Smet J, Wynants E, Cos P, Van Campenhout L (2018) Microbial community dynamics during rearing of black soldier fly larvae (Hermetia illucens) and impact on exploitation potential. Appl Environ Microbiol. https://doi.org/10.1128/AEM.02722-17

8. Chia SY, Tanga CM, Osuga IM, Mohamed SA, Khamis FM, Salifu $D$ et al (2018) Effects of waste stream combinations from brewing industry on performance of Black Soldier Fly, Hermetia illucens (Diptera: Stratiomyidae). PeerJ 6: e5885. https://doi. org/10.7717/peerj.5885

9. Dzepe D, Nana P, Fotso A, Tchuinkam T, Djouaka R (2020a) Influence of larval density, substrate moisture content and feedstock ratio on life history traits of black soldier fly larvae. J Insects as Food Feed 6(2):133-140. https://doi.org/10.3920/JIFF2019.0034

10. Dzepe D, Nana P, Tchuinkam T, Meutchieye F, Lontsi DM, Tchoumbou M, Kimpara MJ (2019) Production and valorization of maggot meal: sustainable source of proteins for indigenous chicks. Asian Journal of Research in Animal and Veterinary Sciences 3(3):1-9

11. Fowles TM, Nansen C (2020) Insect-based bioconversion: value from food waste. Food Waste Management 12:321-346. https ://doi.org/10.1007/978-3-030-20561-4_12

12. Dzepe D, Nana P, Mube KH, Fotso KA, Tchuinkam T, Djouaka R (2020) Role of pupation substrate on post-feeding development of black soldier fly larvae, Hermetia illucens (Diptera: stratiomyidae). Journal of Entomology and Zoology Studies 8(2):760-764

13. Jong-Gill K, Yong-Cheol C, Ji-Young C, Won-Taekim Gil-Sang J, Kwan-Ho P, Sock-Jo H (2008) Ecology of the black soldier fly, Hermetia illucens (Diptera: stratiomyidae) in Korea. Korean Journal of Applied Entomology 47(4):337-343

14. Schiavone A, De Marco M, Martínez S, Dabbou S, Renna M, Madrid J et al (2017) Nutritional value of a partially defatted and a highly defatted black soldier fly larvae (Hermetia illucens $L$.) meal for broiler chickens: apparent nutrient digestibility, apparent metabolizable energy and apparent ideal amino acid digestibility. J Anim Sci Biotechnol 8(51):1-9. https://doi.org/10.1186/ s40104-017-0181-5 
15. Li Q, Zheng L, Cai H, Garza E, Yu Z, Zhou S (2011) From organic waste to biodiesel: black soldier fly, Hermetia illucens, makes it feasible. Fuel 90:1545-1548. https://doi.org/10.1016/j. fuel.2010.11.016

16. Liu X, Chen X, Wang H, Yang Q, ur Rehman K, Li W et al (2017) Dynamic changes of nutrient composition throughout the entire life cycle of black soldier fly. PLoS ONE 12(8):e0182601. https://doi.org/10.1371/journal.pone.0182601

17. Adegnika F, Chalot F, Desile D, Duchemin JP, Etienne J, Le Bris E et al (2004) Gestion durable des déchets et l'assainissement urbain. Ministère des affaires étrangères, IMP graphic, Cosne-sur-Loire

18. Jaza Folefack AJ (2008) The influence of compost use on the production of lettuce (lactuca sativa) in the urban and peri-urban areas of yaoundé (cameroon). Tropicultura 26(4):246-253

19. Lompo F, Segda Z, Gnankambary Z, Ouandaogo N (2009) Influence of natural phosphates on the quality and biodegradation of a corn straw compost. Tropicultura 27(2):105-109

20. Temgoua E, Ngnikam E, Dameni H, Kouedeu KGS (2014) Valorization of household waste by composting in the city of Dschang. Cameroon. Tropicultura 32(1):28-36

21. Ngnikam E, Rousseaux P, Tanawa E, Gourdon R (2002) Application of multicriteria analysis to environmental assessment of solid waste management systems in tropical African cities. J Decision Syst 11(4):479-497

22. Compaoré E, Nanéma LS (2010) Composting and quality of solid urban waste compost from the city of Bobo-Dioulasso. Burkina Faso. Tropicultura 28(4):232-237

23. Kroeckel S, Harjes AGE, Roth I, Katz H, Wuertz S, Susenbeth $A$, Schulz C (2012) When a turbot catches a fly: evaluation of a prepupae meal of the Black Soldier Fly (Hermetia illucens) as fish meal substitute-Growth performance and chitin degradation in juvenile turbot (Psetta maxima). Aquaculture. https://doi. org/10.1016/j.aquaculture.2012.08.041

24. Liland NS, Biancarosa I, Araujo P, Biemans D, Bruckner CG, Waagbo $R$ et al (2017) Modulation of nutrient composition of black soldier fly (Hermetia illucens) larvae by feeding seaweed-enriched media. PLoS ONE 12(8):e0183188. https://doi. org/10.1371/journal.pone.0183188

25. Perednia D, Anderson J, Rice A (2017) A comparison of the greenhouse gas production of black soldier fly larvae versus aerobic microbial decomposition of an organic feed material. Res Rev J Ecol Environ Sci 5(3):10-16

26. Mertenat A, Diener S, Zurbrügg C (2019) Black Soldier Fly biowaste treatment - Assessment of global warming potential. Waste Manag 84:173-181. https://doi.org/10.1016/j.wasma n.2018.11.040

27. Pang W, Hou D, Chen J, Nowar E, Li Z, Hu R, Tomberlin J et al (2020) Reducing greenhouse gas emissions and enhancing carbon and nitrogen conversion in food wastes by the black soldier fly. J Environ Manage 260(15):110066

28. Bava L, Jucker C, Gislon G, Lupi D, Savoldelli S, Zucali M, and Colombini S (2019) Rearing of Hermetia illucens on different organic by-products: influence on growth, waste reduction, and environmental impact. Animals 9:289. https://doi.org/10.3390/ ani9060289

29. Nyakeri EM, Ogola HJO, Ayieko MA, Amimo FA (2017) Valorisation of organic waste material: growth performance of wild black soldier fly larvae (Hermetia illucens) reared on different organic wastes. J Insects as Food Feed 3(3):193-202. https://doi. org/10.3920/JIFF2017.0004

30. Sideris VN, Tsagkarakis AE (2017) Immature Development Time of Hermetia illucens L. in Different Varieties of Feed. Advances in Entomology 5:109-114. https://doi.org/10.4236/ae.2017.53011

31. Nyakeri EM, Ayieko MA, Amimo FA, Salum H, Ogola HJO (2019) An optimal feeding strategy for black soldier fly larvae biomass production and faecal sludge reduction. J Insects as Food Feed 5(3):201-213; https://doi.org/10.3920/JIFF2018.0017

32. Nana P, Kimpara JM, Tiambo KC, Tiogue TC, Youmbi J, Choundong B, Fonkou T (2018) Black soldier flies (Hermetia illucens Linnaeus) as recyclers of organic waste and possible livestock feed. Int J Biol Chem Sci 12:2004-2015. https://doi. org/10.4314/ijbcs.v12i5.4

33. Nguyen T, Tomberlin J, Vanlaerhoven S (2015) Ability of black soldier fly (diptera: stratiomyidae) larvae to recycle food waste. Environ Entomol 44:406-410

34. Cammack J, Tomberlin J (2017) The impact of diet protein and carbohydrate on select life-history traits of the black soldier fly Hermetia illucens (L.) (Diptera: stratiomyidae). Insects 8:56-69

35. Dortmans B, Diener S, Verstappen B, Zurbrügg C (2017) Black Soldier Fly Biowaste Processing - A Step-by-Step Guide Eawag : Swiss Federal Institute of Aquatic Science and Technology. Dübendorf, Switzerland

36. Diener S, Zurbrugg C, Tockner K (2009) Conversion of organic material by black soldier fly larvae: establishing optimal feeding rates. Waste Manag Resour 27:603-610

37. St-Hilaire S, Cranfill K, McGuire M, Mosley E, Tomberlin J, Newton L, Sealey W, Sheppard C, Irving S (2007) Fish offal recycling by the black soldier fly produces a foodstuff high in omega-3 fatty acids. J World Aquac Soc 38:309-313

38. Nguyen TT, Tomberlin JK, Vanlaerhoven S (2013) Influence of resources on Hermetia illucens (Diptera: Stratiomyidae) larval development. J Med Entomol 50:898-906

39. Reim C, Teuschl Y, Blanckenhorn WU (2006) Size-dependent effects of temperature and food stress on energy reserves and starvation resistance in yellow dung flies. Evol Ecol Res 8:1215-1234

40. Tchuinkam T, Mpoame M, Make-Mveinhya B, Simard F, LeleDefo E, Zebaze-Togouet $S$ et al (2011) Optimization of breeding output for larval stage of Anopheles gambiae (Diptera: Culicidae): Prospects for the creation and maintenance of laboratory colony from wild isolates. Bull Entomol Res 101:259-269

41. Mitchell-foster K, Warsame-ali S, Logan C, Rau ME, Lowenberger C (2012) The influence of larval density, food stress, and parasitism on the bionomics of the dengue vector Aedes aegypti (Diptera: Culicidae): implications for integrated vector management. J Vector Ecol. 37:221-229

42. Ojeda-Avila T, Arthur Woods H, Raguso RA (2003) Effects of dietary variation on growth, composition, and maturation of Manduca sexta (Sphingidae: Lepidoptera). J Insect Physiol 49:293-306

43. Devon B (2017) Improving feeding efficiencies of black soldier fly larvae, Hermetia illucens (L., 1758) (Diptera: Stratiomyidae: Hermetiinae) through manipulation of feeding conditions for industrial mass rearing. Thesis presented in partial fulfilment of the requirements for the degree of Master of AgriScience in the Faculty of Conservation Ecology and Entomology at Stellenbosch University

44. Simpson SJ, Sword GA, Lorch PD, Couzin ID (2006) Cannibal crickets on a forced march for protein and salt. Proc Natl Acad Sci USA 103:4152-4156

45. Cheng J, Chiu S, Lo I (2017) Effects of moisture content of food waste on residue separation, larval growth and larval survival in black soldier fly bioconversion. Waste Manag 67:315-323

46. Joly $\mathrm{G}$ (2018) Valorising organic waste using the black soldier fly (Hermetia illucens), in Ghana. Degree Project in Environmental Engineering and Sustainable Infrastructure, KTH Royal Institute of Technology

47. Diener S, Solano N, Gutiérrez F, Zurbrügg C, Tockner K (2011) Biological treatment of municipal organic waste using black soldier fly larvae. Waste Biomass Valoriz 2(4):357-363 
48. Gold M, Tomberlin J, Diener S, Zurbrügg C, Mathys A (2018) Decomposition of biowaste macronutrients, microbes, and chemicals in black soldier fly larval treatment: A review. Waste Manag 82:302-318
Publisher's Note Springer Nature remains neutral with regard to jurisdictional claims in published maps and institutional affiliations. 